(2) Open Access Full Text Article

REVIEW

\title{
Potential use of STAT3 inhibitors in targeted prostate cancer therapy: future prospects
}

This article was published in the following Dove Press journal:

OncoTargets and Therapy

3 July 2012

Number of times this article has been viewed

\author{
Adetola L Shodeinde' \\ Beverly E Barton ${ }^{2}$ \\ 'Department of Pharmacology and \\ Physiology, New Jersey Medical \\ School, University of Medicine and \\ Dentistry of New Jersey, Newark, NJ, \\ USA; ${ }^{2}$ Department of Surgery, New \\ Jersey Medical School, University of \\ Medicine and Dentistry of New Jersey, \\ Newark, NJ, USA
}

\begin{abstract}
In 2012, prostate cancer will once again be the second-leading cause of cancer death of American males. Although initially treatable, prostate cancer can recur in a hormone refractory form that is not responsive to current available therapies. The mortality rate associated with hormone refractory prostate cancer is high, and there is an urgent need for new therapeutic agents to treat prostate cancer. A common feature of prostate cancer is the dependence on activated signal transducer and activator of transcription 3 (STAT3), a transcription factor, for survival. More important, inhibition of STAT3 has been shown to induce apoptosis in prostate cancer cells. In recent years, inhibitors of STAT3 have emerged as promising molecular candidates for targeted prostate cancer therapy. The aim of this review is to examine the role of STAT3 in prostate cancer and how inhibitors of STAT3 could advance the quest for treatment of the disease. Janus kinase 2 (JAK2)-targeted therapy appears very promising in the treatment of prostate cancer. It has been shown to decrease symptoms associated with myeloproliferative disorders and increase overall survival of patients compared with the best available therapy. In addition to improved outcome, many JAK2 inhibitors have been found to be tolerable with no adverse impact on quality of life. As such, JAK2 inhibitors may play an important role in the management of patients with prostate cancer. Current studies are evaluating the role of JAK2 inhibitors in solid tumors. Pending clinical trial results will determine the future direction of JAK2 inhibitors in the treatment of patients with prostate cancer.
\end{abstract}

Keywords: JAK2 inhibitors, transcription factors, therapy development, targeted cancer therapy

\section{Introduction}

It is estimated that there will be 241,740 new prostate cancer cases in 2012, with a projected death toll of 28,170 within the same year. ${ }^{1}$ Once again prostate cancer will be the second-leading cause of cancer death of American males. Current treatment options available for prostate cancer include (1) active surveillance, (2) surgery, (3) radiation therapy, (4) hormone therapy, (5) chemotherapy, and (6) immunotherapy. ${ }^{2}$ The treatment given varies and it depends on age, overall health of individual, and the stage of disease. Prostate cancer, although initially treatable, can recur in an androgeninsensitive or hormone-refractory form that is not responsive to current therapies. ${ }^{3}$ The mortality rate associated with recurrent prostate cancer is high; therefore, effective therapies to treat the disease, especially those adequate for recurrent cases, are in great demand.

Novel therapeutic agents designed to specifically target prostate cancer are needed. Targeted prostate cancer therapy using inhibitors of the signal transduction and activator 
of transcription 3 (STAT3) appears promising. A common feature of many prostate cancers is their dependence for survival on the activated form of STAT3. Importantly, inhibition of STAT3 has been shown to induce apoptosis in prostate cancer cells. ${ }^{4-6}$ The targeting of STAT3 could in practice serve as a suitable option for therapeutic intervention. This review will focus on STAT3, its role in prostate cancer, and how inhibitors of STAT3 could advance the quest for treatment of the disease.

\section{STATs}

Once activated, transcription factors are proteins that regulate the genome by either inducing or repressing gene expression. Transcription factors bind to specific DNA sequences in the genome upstream or near the promoter region of their gene of interest. STATs are now known to activate many genes involved in malignant progression and have recently emerged as ideal molecular targets for cancer therapy. ${ }^{7-9}$ STATs were originally discovered in their role as cytokine signaling proteins and comprise seven members: STAT1, STAT2, STAT3, STAT4, STAT5a, STAT5b, and STAT6. ${ }^{10}$

The general structure of STATs includes a STAT dimerization domain at the $\mathrm{NH}_{2}$ terminus, a coiled-coil domain involved in protein-protein interactions, a central DNA binding domain, a Src homology 2 domain, and a $\mathrm{COOH}$ terminus encoding the transcription activation domain. ${ }^{11,12}$ STATs are activated in response to ligation of receptors by cytokines, hormones, and growth factors through phosphorylation of tyrosine and serine residues. ${ }^{11,12}$ For example, signaling by the interleukin 6 (IL-6) family generally induces phosphorylation of STAT3. ${ }^{13,14}$ Once phosphorylated, STATs undergo a conformational rearrangement; dimerization then occurs through interactions between phosphotyrosine and the Src homology 2 domain. ${ }^{15}$ After activation, phosphorylated STATs dimers translocate to the nucleus and bind enhancer elements of target genes. In normal cells, the activation of STATs is tightly regulated and transient. However, constitutive activation of STATs has been associated with the malignant state. Constitutive activation of STAT3 in particular has been shown to be addictive: disrupting activation or expression or nuclear translocation leads to apoptosis of transformed but not benign cells. , $^{5,16}$

\section{Role of STAT3 in cancer}

Originally known as acute-phase response factor, STAT3 was identified and cloned within the IL-6 pathway as a mediator of the acute-phase inflammatory response. ${ }^{17,18}$ However, it is now known that STAT3 is activated by an array of ligand-receptor interactions, including those mentioned earlier (cytokines, hormones, and growth factors), and also by activation of intracellular kinases. ${ }^{11,12}$ STAT3 can also be activated by growth factor receptors that possess intrinsic tyrosine-kinase activity. These include epidermal growth factor receptor, hepatocyte growth factor receptor (also known as c-Met), and the platelet-derived growth factor receptor. ${ }^{19-23}$ Non-receptor, cytoplasmic tyrosine kinases (ie, Abelson leukemia protein and Src-related kinases) also activate STAT3. ${ }^{24-26}$

In benign cells, STAT3 activation is initiated by the binding of a ligand to its receptor, which leads to dimerization of the cytoplasmic domain of the receptor and activation of associated Janus tyrosine kinases (Janus kinase 1 [JAK1], Janus kinase 2 [JAK2], or tyrosine kinase 2 [TYK2]) (Figure 1). Activated upstream kinases in turn phosphorylate STAT3 on its conserved tyrosine residue $\left(\mathrm{Tyr}^{705}\right)$, which allows for dimerization of STAT3. The STAT3 dimer then translocates to the nucleus where it regulates transcription. Dimerization of receptors with intrinsic tyrosine kinase activity can also directly phosphorylate STAT3.

In malignant cells, the requirement for ligand binding is often lost. A number of human cancers have been reported to express constitutively activated STAT $3^{12,27}$ - these include myeloma, lymphoma, head and neck squamous cell carcinoma, melanoma, and breast, ovarian, lung, pancreatic, and prostate cancer. Glycoprotein 130 kDA-mediated STAT3 activation, in particular, has been linked to many types of solid and hematological tumors. ${ }^{28-30}$ The glycoprotein $130 \mathrm{kDA}$ receptor complex, part of the IL-6 signal transduction pathway, is well known for intracellular activation of JAK-TYKs as well as STATs. This mechanism of ligandindependent activation may be important in cancer.

STAT3 is essential for embryonic stem cell growth and renewal; disruption of STAT3 activity results in embryonic lethality in mice. ${ }^{31,32}$ STAT3-responsive elements have been identified in several genes influencing cell cycle progression, apoptosis, or metastasis. These genes include cyclin D1, B-cell lymphoma extra large, B-cell lymphoma 2, and matrix metalloproteinase $9 .^{33-37}$ The upregulation of the expression of these genes in cancers is well known. ${ }^{38-43}$ STAT3 is also an important mediator of angiogenesis, as it has been shown to be required for vascular endothelial growth factor signaling. ${ }^{446}$ When persistently activated, STAT3 behaves as a proto-oncogene ${ }^{47-50}$ and is believed to be required for the malignant phenotype. The mechanism of action of how STAT3 becomes persistently activated is unknown; although, in bladder cancer, the CDC91 L1 oncogene, activated by 


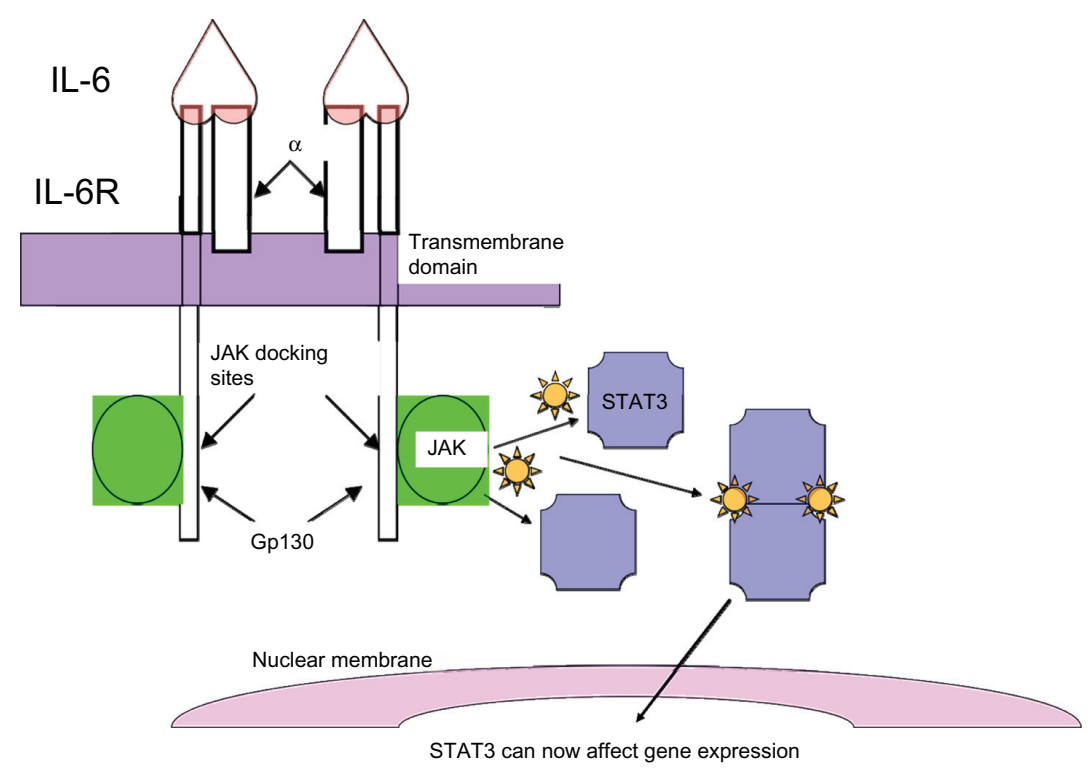

Figure I Signal transducer and activator of transcription 3 (STAT3) activation: STAT3 activation is initiated by binding of the ligand, interleukin 6 (IL-6), to its receptor, which consists of glycoprotein 80 kDA and glycoprotein I30 kDA (gp I30). Binding of IL-6 to the receptors leads to dimerization of the cytoplasmic domain of the gp I 30 peptide, with subsequent activation of associated Janus tyrosine kinases, notably Janus kinase 2 (JAK2). The activated JAKs in turn phosphorylate STAT3, which allows for dimerization of STAT3. The STAT3 dimer then translocates to the nucleus where it regulates transcription.

Abbreviations: $\alpha$, alpha; IL-6R, interleukin- 6 receptor.

a chromosomal translocation, leads to persistent STAT3 activation..$^{51}$ In prostate cancer, abnormal activation of STAT3 is thought to be responsible for neoplastic progression of prostate cells. ${ }^{52}$ Prostate cancer cells also expressing persistently activated STAT3 have been shown to become dependent on it for survival; disruption of expression of persistently activated STAT3 in prostate cancer cells results in apoptosis. ${ }^{5,6,16}$ This makes STAT3 an excellent molecular candidate for prostate cancer therapy.

In recent years, STAT3 inhibitors have emerged as promising anticancer therapies. ${ }^{53-55}$ STAT3 signaling is advantageous because (1) constitutive activation of STAT3 is seen in many cancers; (2) STAT3 is associated with many genes involved in cell cycle progression, apoptosis, and metastasis; and (3) STAT3 is a single target. The interruption of STAT3 signaling can prompt the development of molecules effective in the treatment of a variety of tumors.

Different strategies have been established to inhibit STAT3 activity (Table 1). The most popular approach inhibits STAT3 by disrupting upstream tyrosine kinases (JAK1, JAK2, or TYK2) responsible for its activation. Other approaches such as oligonucleotides (antisense, decoy, g-quartet, and binding sequences), dominant-negative expression vectors, and siRNA methodologies target STAT3 directly. ${ }^{6,12,56-60}$ Oligonucleotides, in particular, are very attractive in theory, but a practical method to deliver oligonucleotides in a clinical setting has not been established.
However, a possible approach to introduce oligonucleotides in a clinical setting is to use peptide-mediated transport, coupling a cell-penetrating peptide to a therapeutic payload (ie, peptide nucleic acid). ${ }^{61,62}$ Cell-penetrating peptides are advantageous because cell specificity in the sequence and organelle specificity, using nuclear localization signals, can be achieved. Less popular approaches target (1) physiological regulators of STAT3 (ie, suppressor of cytokine signaling [SOCS] proteins and protein inhibitors of activated STATs [PIAS]) or (2) STAT3 interacting nuclear proteins that help with STAT3 transcription regulation. ${ }^{12}$ SOCS proteins and PIAS are negative regulators of STAT3 that block

Table I Pharmacological strategies to inhibit signal transducer and activator of transcription 3 (STAT3) signaling: different methods have been established including indirect, direct, or alternate inhibition of STAT3

\begin{tabular}{ll}
\hline Inhibition type & Examples \\
\hline Indirect & Small molecule inhibitors of JAK, SRC, \\
& BCR-ABL, EGFR, c-Met \\
Direct & $\begin{array}{l}\text { Antisense and decoy oligonucleotides, cell } \\
\text { penetrating peptides, dominant-negative } \\
\text { expression vectors, siRNA }\end{array}$ \\
Alternate & $\begin{array}{l}\text { Inhibitors of physiological regulators of STAT3 } \\
\text { signaling; inhibitors of STAT3 interacting } \\
\end{array}$ \\
& proteins \\
\hline
\end{tabular}

Abbreviations: BCR-ABL, breakpoint cluster region-Abelson leukemia protein EGFR, epidermal growth factor receptor; JAK, Janus kinase; siRNA, small interfering RNA; SRC, sarcoma. 
STAT3 activation. ${ }^{63-65}$ SOCS proteins bind to JAK1, JAK2, or TYK2 to inhibit STAT3 activity; PIAS interact directly with STAT3 and block its DNA-binding activity. However, these proteins are not totally specific for STAT3, as they have other functions in the cell. This makes them less attractive for therapeutic development.

Studies have shown that inhibition of STAT3 leads to cessation of tumor cell growth and apoptosis. Experiments conducted in the human myeloma cell line U266 resulted in two major findings: (1) the cell line was sensitive to AG490 (a JAK2 inhibitor that disrupts STAT3 activation; also a potent inhibitor of epidermal growth factor receptor, which can also interrupt STAT3 activity) and (2) the transfection of the cell line with a dominant-negative form of STAT3 (DNSTAT3), which blocks STAT3 function, induced apoptosis. ${ }^{66}$ In another study, the transfection of DN-STAT3 in head and neck squamous cell carcinoma lines lead to the failure of cells to divide. ${ }^{67}$ The use of DN-STAT3 also showed therapeutic ability in a melanoma model. ${ }^{68}$ AG490 has also been shown to suppress growth in the classic cell lines of prostate cancer, DU-145 and PC3. ${ }^{69}$ Another prostate cancer cell line, TSU-Pr1, was also sensitive to the effects of AG490 in the same study.

\section{JAK2 inhibitors: a closer look}

STAT3 signaling by cytokines is mediated through upstream tyrosine kinases JAK1, JAK2, or TYK2. Because of their downstream targets involved in apoptosis, proliferation, and differentiation, these tyrosine kinases are also potential therapeutic targets for cancer therapy. The development of JAK2 inhibitors, in particular, has recently been of great interest to researchers. ${ }^{70-74}$ A single point mutation within JAK2 was found to be linked to many myeloproliferative disorders. ${ }^{75-79}$ A substitution of valine by phenylalanine at amino acid 617 (JAK2 ${ }^{\mathrm{V} 617 \mathrm{~F}}$ ) was found in $95 \%$ of patients with polycythemia vera (PV), and $50 \%$ of patients with essential thrombocythemia (ET), or primary myelofibrosis. ${ }^{55-59}$ Point mutations or insertions/ deletions in JAK2 exon 12 have also been implicated in JAK2 ${ }^{\mathrm{V} 617 \mathrm{~F}}$-negative PV patients. ${ }^{80-83}$ The JAK2 ${ }^{\mathrm{V} 617 \mathrm{~F}}$ mutation is located within JAK2's autoregulatory JAK homology 2 pseudokinase domain, which, interestingly, lacks catalytic activity. ${ }^{84}$ However, the JAK2 ${ }^{\mathrm{V} 617 \mathrm{~F}}$ mutation causes JAK2 to be constitutively activated and results in increased activity and phosphorylation of downstream targets such as STATs. ${ }^{79}$ JAK2 inhibitors appear promising in the treatment of hematological and solid tumor cancers that show aberrant activation of the JAK2-STAT signaling pathway.
Ruxolitinib (Incyte Corporation, Wilmington, DE), also known as INCB018424, is a potent inhibitor of JAK1 and JAK2 ${ }^{85}$ It was among the first JAK2 inhibitors tested in myeloproliferative disorders. Ruxolitinib administered to JAK $2^{\mathrm{V} 617 \mathrm{~F}}$-positive mice reduced levels of circulating inflammatory cytokines and splenomegaly, which ultimately increased survival. ${ }^{68,86}$ Although the precise mode of action of ruxolitinib is not well understood, it is believed to competitively interact with the adenosine triphosphate (ATP) or substrate-binding site of JAK 1 and JAK2. ${ }^{71}$ Ruxolitinib showed promising results in phase III clinical trials from patients with myelofibrosis (primary, post-PV, or post-ET myelofibrosis); more than $35 \%$ of patients demonstrated reduction in spleen size and more than $50 \%$ showed reduction in myelofibrosisrelated symptoms when ruxolitinib was taken orally twice daily, compared with the best available therapy (hydroxyurea or glucocorticoids) and placebo. ${ }^{69}$ The US Food and Drug Administration approved ruxolitinib in November 2011 as the first drug treatment ever for myelofibrosis; ruxolitinib also was the first JAK2 inhibitor approved for therapy. ${ }^{86}$ Clinical trials to study the effects of orally administered ruxolitinib in patients with androgen-independent, metastatic prostate cancer started in March 2008. ${ }^{87}$ The study successfully advanced to phase II clinical trials. Patients were administered ruxolitinib $25 \mathrm{mg}$ tablets twice daily with water over 21-day cycles for as long as the drug was tolerated. However, as of January 2012, the study was terminated after it was shown that fewer than two of the 22 patients showed a prostate-specific antigen response of $50 .{ }^{87}$

AZD1480 is a potent inhibitor of JAK1 and JAK2. In preclinical studies, AZD1480 inhibited tumor growth in constitutively activated STAT3 solid tumor cell lines. ${ }^{57}$ These cell lines, including DU-145 (a classic human prostate cancer cell line), had constitutive STAT3 action via IL-6 stimulation. AZD1480 also blocked constitutive STAT3 signaling and phosphorylation following suppression of tumor growth. ${ }^{57}$ AZD1480 is now being studied in phase I/II clinical trials in patients with myelofibrosis and phase I clinical trials, alone or with docetaxel (Sanofi-Aventis, Paris, France), in patients with advanced solid malignancies. ${ }^{88}$

Numerous other novel JAK2 inhibitors are still being studied in clinical trials (Table 2). TG101348 is another potent inhibitor of JAK2. ${ }^{72}$ TG101348, an ATP-competitive inhibitor, resides in the ATP-binding pocket of JAK2 where it exemplifies its inhibitory effects. ${ }^{72}$ TG101348 disrupts JAK2-induced phospho-STAT3 signaling in cultured and primary cells from patients with JAK2 ${ }^{\mathrm{V} 617 \mathrm{~F}}$-positive myeloproliferative disorders. ${ }^{89,90}$ TG101348 is now being studied 
Table 2 Novel Janus kinase (JAK) inhibitors in development: numerous JAKI and JAK2 inhibitors are being developed in clinical trials for treatment of myeloproliferative diseases and solid malignancies

\begin{tabular}{llll}
\hline Name & $\begin{array}{l}\text { Stage of } \\
\text { development }\end{array}$ & $\begin{array}{l}\text { Kinase } \\
\text { selectivity }\end{array}$ & Company \\
\hline AZDI480 & Phase I/II & JAKI, JAK2 & AstraZeneca \\
TGI0I348 & Phase I/II & JAK2 & TargeGen Inc \\
CYT387 & Phase I/II & JAKI, JAK2 & YM BioSciences Inc \\
NS-018 & Phase I/II & JAK2 & NS Pharma, Inc \\
SBI5I8 & Phase I/II & JAK2 & S*BIO Pte Ltd \\
CEP-70I & Phase II & JAK2 & Cephalon, Inc \\
XL0I9 & Phase I & JAK2 & Exelixis, Inc \\
\hline
\end{tabular}

in phase I/II clinical trials in patients with myelofibrosis. SB1518, CYT387, NS-018, CEP-701, and XL019 are also JAK2 inhibitors in phase I/II clinical trials for treatment in patients with myeloproliferative disorders, with promising future clinical trials extending to patients with solid malignancies. ${ }^{70,73,91-94}$

\section{Conclusion}

Constitutively activated STAT3 has been implicated in a number of human cancers, including prostate cancer. As a result, STAT3 inhibitors have emerged as ideal molecular targets for cancer therapy. Targeted prostate cancer therapy using JAK2 inhibitors, in particular, appears very promising in the treatment of the disease. The study of JAK2 inhibitors in myeloproliferative disorders has provided a basis for the study of these novel molecules in solid tumors. JAK2 targeted therapy has been shown to decrease symptoms associated with myeloproliferative disorders and increase overall survival of patients compared with the best available therapy. In addition to improved outcome, many JAK2 inhibitors have been found to be tolerable with no adverse impact on quality of life. As such, JAK2 inhibitors may play an important role in the management of patients with prostate cancer. Current studies are evaluating the role of JAK2 inhibitors in solid tumors. Pending clinical trial results will determine the future direction of JAK2 inhibitors in the treatment of patients with prostate cancer.

\section{Disclosure}

The authors report no conflicts of interest in this work.

\section{References}

1. Siegel R, Naishadham D, Jemal A. Cancer statistics, 2012. CA Cancer J Clin. 2012;62(1):10-29.

2. National Cancer Institute. Prostate cancer treatment $\left(\mathrm{PDQ}^{\circledR}\right)$. Bethesda, MD: National Cancer Institute; 2011. Available from: http://www.cancer.gov/cancertopics/pdq/treatment/prostate/Patient/page4. Accessed Dec 16, 2011
3. Denmeade SR, Isaacs JT. Programmed cell death (apoptosis) and cancer chemotherapy. Cancer Control. 1996;3(4):303-309.

4. Lou W, Ni Z, Dyer K, Tweardy DJ, Gao AC. Interleukin-6 induces prostate cancer cell growth accompanied by activation of STAT3 signaling pathway. Prostate. 2000;42(3):239-242.

5. Mora LB, Buettner R, Seigne J, et al. Constitutive activation of STAT3 in human prostate tumors and cell lines: direct inhibition of STAT3 signaling induces apoptosis of prostate cancer cells. Cancer Res. 2002;62(22):6659-6666.

6. Barton BE, Karras JG, Murphy TF, Barton A, Huang HF. Signal transducer and activator of transcription 3 (STAT3) activation in prostate cancer: direct STAT3 inhibition induces apoptosis in prostate cancer lines. Mol Cancer Ther. 2004;3(1):11-20.

7. Bowman T, Garcia R, Turkson J, Jove R. STATs in oncogenesis. Oncogene. 2000;19(21):2474-2488.

8. Darnell JE Jr. STATs and gene regulation. Science. 1997;277(5332): $1630-1635$

9. Bromberg J, Darnell JE Jr. The role of STATs in transcriptional control and their impact on cellular function. Oncogene. 2000;19(21): 2468-2473.

10. Darnell JE Jr, Kerr IM, Stark GR. JAK-STAT pathways and transcriptional activation in response to IFNs and other extracellular signaling proteins. Science. 1994;264(5164):1415-1421.

11. Darnell JE Jr. Transcription factors as targets for cancer therapy. Nat Rev Cancer. 2002;2(10):740-749.

12. Yu H, Jove R. The STATs of cancer: new molecular targets come of age. Nat Rev Cancer. 2004;4(2):97-105.

13. Ihle JN. STATs and MAPKs: obligate or opportunistic partners in signaling. Bioessays. 1996;18(2):95-98.

14. Aaronson DS, Horvath CM. A road map for those who don't know JAK-STAT. Science. 2002;296(5573):1653-1655.

15. Chen X, Vinkemeier U, Zhao Y, Jeruzalmi D, Darnell JE Jr, Kuriyan J. Crystal structure of a tyrosine phosphorylated STAT-1 dimer bound to DNA. Cell. 1998;93(5):827-839.

16. Barton BE, Murphy TF, Shu P, Huang HF, Meyenhofer M, Barton A. Novel single-stranded oligonucleotides that inhibit signal transducer and activator of transcription 3 induce apoptosis in vitro and in vivo in prostate cancer cell lines. Mol Cancer Ther. 2004;3(10):1183-1191.

17. Wegenka UM, Buschmann J, Lütticken C, Heinrich PC, Horn F. Acute-phase response factor, a nuclear factor binding to acute-phase response elements, is rapidly activated by interleukin- 6 at the posttranslational level. Mol Cell Biol. 1993;13(1):276-288.

18. Akira S, Nishio Y, Inoue M, et al. Molecular cloning of APRF, a novel IFN-stimulated gene factor $3 \mathrm{p} 91$-related transcription factor involved in the gp130-mediated signaling pathway. Cell. 1994;77(1):63-71.

19. Silvennoinen O, Schindler C, Schlessinger J, Levy DE. Ras-independent growth factor signaling by transcription factor tyrosine phosphorylation. Science. 1993;261(5129):1736-1739.

20. Zhong Z, Wen Z, Darnell JE Jr. STAT3: a STAT family member activated by tyrosine phosphorylation in response to epidermal growth factor and interleukin-6. Science. 1994;264(5155):95-98.

21. Ruff-Jamison S, Zhong Z, Wen Z, Chen K, Darnell JE Jr, Cohen S. Epidermal growth factor and lipopolysaccharide activate STAT3 transcription factor in mouse liver. J Biol Chem. 1994;269(35):21933-21935

22. Hung W, Elliott B. Co-operative effect of c-Src tyrosine kinase and STAT3 in activation of hepatocyte growth factor expression in mammary carcinoma cells. J Biol Chem. 2001;276(15):12395-12403.

23. Zhang YW, Wang LM, Jove R, Vande Woude GF. Requirement of STAT3 signaling for HGF/SF-Met mediated tumorigenesis. Oncogene. 2002;21(2):217-226.

24. Parsons JT, Parsons SJ. Src family protein tyrosine kinases: cooperating with growth factor and adhesion signaling pathways. Curr Opin Cell Biol. 1997;9(2):187-192.

25. Irby RB, Yeatman TJ. Role of Src expression and activation in human cancer. Oncogene. 2000;19(49):5636-5642.

26. Danial NN, Rothman P. JAK-STAT signaling activated by Abl oncogenes. Oncogene. 2000;19(21):2523-2531. 
27. Buettner R, Mora LB, Jove R. Activated STAT signaling in human tumors provides novel molecular targets for therapeutic intervention. Clin Cancer Res. 2002;8(4):945-954.

28. Stuhlmann-Laeisz C, Lang S, Chalaris A, et al. Forced dimerization of gp130 leads to constitutive STAT3 activation, cytokine-independent growth, and blockade of differentiation of embryonic stem cells. Mol Biol Cell. 2006;17(7):2986-2995.

29. Sriuranpong V, Park JI, Amornphimoltham P, Patel V, Nelkin BD, Gutkind JS. Epidermal growth factor receptor-independent constitutive activation of STAT3 in head and neck squamous cell carcinoma is mediated by the autocrine/paracrine stimulation of the interleukin 6/ gp130 cytokine system. Cancer Res. 2003;63(11):2948-2956.

30. Selander KS, Li L, Watson L, et al. Inhibition of gp130 signaling in breast cancer blocks constitutive activation of STAT3 and inhibits in vivo malignancy. Cancer Res. 2004;64(19):6924-6933.

31. Niwa H, Burdon T, Chambers I, Smith A. Self-renewal of pluripotent embryonic stem cells is mediated via activation of STAT3. Genes Dev. 1998;12(13):2048-2060.

32. Boeuf H, Hauss C, Graeve FD, Baran N, Kedinger C. Leukemia inhibitory factor-dependent transcriptional activation in embryonic stem cells. J Cell Bio. 1997;138(6):1207-1217.

33. Fukada T, Hibi M, Yamanaka Y, et al. Two signals are necessary for cell proliferation induced by a cytokine receptor gp130: involvement of STAT3 in anti-apoptosis. Immunity. 1996;5(5):449-460.

34. Puthier D, Bataille R, Amiot M. IL-6 up-regulates Mcl-1 in human myeloma cells through JAK/STAT rather than ras/MAP kinase pathway. Eur J Immunol. 1999;29(12):3945-3950.

35. Karni R, Jove R, Levitzki A. Inhibition of pp60c-Src reduces Bcl-xL expression and reverses the transformed phenotype of cells overexpressing EGF and HER-2 receptors. Oncogene. 1999;18(33):4654-4662.

36. Ivanov VN, BhoumikA, Krasilnikov M, et al. Cooperation between STAT3 and c-jun suppresses Fas transcription. Mol Cell. 2001;7(3):517-528.

37. Sinibaldi D, Wharton W, Turkson J, Bowman T, Pledger WJ, Jove R. Induction of p21WAF1/CIP1 and cyclin D1 expression by the Src oncoprotein in mouse fibroblasts: role of activated STAT3 signaling. Oncogene. 2000;19(48):5419-5427.

38. Kijima T, Niwa H, Steinman RA, et al. STAT3 activation abrogates growth factor dependence and contributes to head and neck squamous cell carcinoma tumor growth in vivo. Cell Growth Differ. 2002;13(8): 355-362.

39. Lebedeva I, Rando R, Ojwang J, Cossum P, Stein CA. Bcl-xL in prostate cancer cells: effects of overexpression and down-regulation on chemosensitivity. Cancer Res. 2000;60(21):6052-6060.

40. Li X, Marani M, Mannucci R, et al. Overexpression of Bcl-xL underlies the molecular basis for resistance to staurosporine-induced apoptosis in PC-3 cells. Cancer Res. 2001;61(4):1699-1706.

41. Yoshida T, Hanada T, Tokuhisa T, et al. Activation of STAT3 by the hepatitis $\mathrm{C}$ virus core protein leads to cellular transformation. $J$ Exp Med. 2002;196(5):641-653.

42. Yu Q, Geng Y, Sicinski P. Specific protection against breast cancers by cyclin D1 ablation. Nature. 2001;411(6841):1017-1021.

43. Masuda M, Suzui M, Yasumatu R, et al. Constitutive activation of signal transducers and activators of transcription 3 correlates with cyclin D1 overexpression and may provide a novel prognostic marker in head and neck squamous cell carcinoma. Cancer Res. 2002;62(12):3351-3355.

44. Bartoli M, Platt D, Lemtalsi T, et al. VEGF differentially activates STAT3 in microvascular endothelial cells. FASEB J. 2003;17(11):1562-1564.

45. Yahata Y, Shirakata Y, Tokumaru S, et al. Nuclear translocation of phosphorylated STAT3 is essential for vascular endothelial growth factor-induced human dermal microvascular endothelial cell migration and tube formation. J Biol Chem. 2003;278(41):40026-40031.

46. Niu G, Wright KL, Huang M, et al. Constitutive STAT3 activity up-regulates VEGF expression and tumor angiogenesis. Oncogene. 2002;21(13):2000-2008.

47. Yu CL, Meyer DJ, Campbell GS, et al. Enhanced DNA-binding activity of a STAT3-related protein in cells transformed by the Src oncoprotein. Science. 1995;269(5220):81-83.
48. Garcia R, Yu CL, Hudnall A, et al. Constitutive activation of STAT3 in fibroblasts transformed by diverse oncoproteins and in breast carcinoma cells. Cell Growth Differ. 1997;8(12):1267-1276.

49. Bromberg JF, Horvath CM, Besser D, Lathem WW, Darnell JE Jr. STAT3 activation is required for cellular transformation by v-src. Mol Cell Biol. 1998;18(5):2553-2558.

50. Turkson J, Bowman T, Garcia R, Caldenhoven E, De Groot RP, Jove R. STAT3 activation by Src induces specific gene regulation and is required for cell transformation. Mol Cell Biol. 1998;18(5):2545-2552.

51. Guo Z, Linn JF, Wu G, et al. CDC91L1 (PIG-U) is a newly discovered oncogene in human bladder cancer. Nat Med. 2004;10(4):374-381.

52. Barton BE, Murphy TF, Adem P, Watson RA, Irwin RJ, Huang HF. IL-6 signaling by STAT3 participates in the change from hyperplasia to neoplasia in NRP-152 and NRP-154 rat prostatic epithelial cells. BMC Cancer. 2001;1:19.

53. Frank DA. STAT signaling in cancer: insights into pathogenesis and treatment strategies. Cancer Treat Res. 2003;115:267-291.

54. Catlett-Falcone R, Dalton WS, Jove R. STAT proteins as novel targets for cancer therapy: signal transducer an activator of transcription. Curr Opin Oncol. 1999;11(6):490-496.

55. Turkson J, Jove R. STAT proteins: novel molecular targets for cancer drug discovery. Oncogene. 2000;19(56):6613-6626.

56. Konnikova L, Kotecki M, Kruger MM, Cochran BH. Knockdown of STAT3 expression by RNAi induces apoptosis in astrocytoma cells. BMC Cancer. 2003;3:23.

57. Leong PL, Andrews GA, Johnson DE, et al. Targeted inhibition of STAT3 with a decoy oligonucleotide abrogates head and neck cancer cell growth. Proc Natl Acad Sci U S A. 2003;100(7):4138-4143.

58. Lewis HD, Winter A, Murphy TF, Tripathi S, Pandey VN, Barton BE. STAT3 inhibition in prostate and pancreatic cancer lines by STAT3 binding sequence oligonucleotides: differential activity between $5^{\prime}$ and 3' ends. Mol Cancer Ther. 2008;7(6):1543-1550.

59. Sen M, Tosca PJ, Zwayer C, et al. Lack of toxicity of a STAT3 decoy oligonucleotide. Cancer Chemother Pharmacol. 2009;63(6): 983-995.

60. Jing N, Zhu Q, Yuan P, Li Y, Mao L, Tweardy DJ. Targeting signal transducer and activator of transcription 3 with G-quartet oligonucleotides: a potential novel therapy for head and neck cancer. Mol Cancer Ther. 2006;5(2):279-286.

61. Said Hassane F, Saleh AF, Abes R, Gait MJ, Lebleu B. Cell penetrating peptides: overview and applications to the delivery of oligonucleotides. Cell Mol Life Sci. 2010;67(5):715-726.

62. Lewis HD, Husain A, Donnelly RJ, et al. Creation of a novel peptide with enhanced nuclear localization in prostate and pancreatic cancer cell lines. BMC Biotechnol. 2010;10:79.

63. Starr R, Hilton DJ. Negative regulation of the JAK/STAT pathway. Bioessays. 1999;21(1):47-52.

64. Naka T, Fujimoto M, Kishimoto T. Negative regulation of cytokine signaling: STAT-induced STAT inhibitor. Trends Biochem Sci. 1999;24(10):394-398.

65. Shuai K. Modulation of STAT signaling by STAT-interacting proteins. Oncogene. 2000;19(21):2638-2644.

66. Catlett-Falcone R, Landowski TH, Oshiro MM, et al. Constitutive activation of STAT3 signaling confers resistance to apoptosis in human U266 myeloma cells. Immunity. 1999;10(1):105-115.

67. Grandis JR, Drenning SD, Chakraborty A, et al. Requirement of STAT3 but not STAT1 activation for epidermal growth factor receptor-mediated cell growth In vitro. J Clin Invest. 1998;102(7):1385-1392.

68. Niu G, Heller R, Catlett-Falcone R, et al. Gene therapy with dominantnegative STAT3 suppresses growth of the murine melanoma B16 tumor in vivo. Cancer Res. 1999;59(20):5059-5063.

69. Ni Z, Lou W, Leman ES, Gao AC. Inhibition of constitutively activated STAT3 signaling pathway suppresses growth of prostate cancer cells. Cancer Res. 2000;60(5):1225-1228.

70. Quintás-Cardama A, Kantarjian H, Cortes J, Verstovsek S. Janus kinase inhibitors for the treatment of myeloproliferative neoplasias and beyond. Nat Rev Drug Discov. 2011;10(2):127-140. 
71. Walz C, Cross NC, Van Etten RA, Reiter A. Comparison of mutated ABL1 and JAK2 as oncogenes and drug targets in myeloproliferative disorders. Leukemia. 2008;22(7):1320-1334.

72. Wernig G, Kharas MG, Okabe R, et al. Efficacy of TG101348, a selective JAK2 inhibitor, in treatment of a murine model of JAK2V617F-induced polycythemia vera. Cancer Cell. 2008;13(4):311-320.

73. Pardanani A, Lasho T, Smith G, Burns CJ, Fantino E, Tefferi A. CYT387, a selective JAK1/JAK2 inhibitor: in vitro assessment of kinase selectivity and preclinical studies using cell lines and primary cells from polycythemia vera patients. Leukemia. 2009;23(8): 1441-1445.

74. Hedvat M, Huszar D, Herrmann A, et al. The JAK2 inhibitor AZD1480 potently blocks STAT3 signaling and oncogenesis in solid tumors. Cancer Cell. 2009;16(6):487-497.

75. James C, Ugo V, Le Couédic JP, et al. A unique clonal JAK2 mutation leading to constitutive signalling causes polycythaemia vera. Nature. 2005;434(7037):1144-1148.

76. Kralovics R, Passamonti F, Buser AS, et al. A gain-of-function mutation of JAK2 in myeloproliferative disorders. $N$ Engl J Med. 2005;352(17):1779-1790.

77. Levine RL, Wadleigh M, Cools J, et al. Activating mutation in the tyrosine kinase JAK2 in polycythemia vera, essential thrombocythemia, and myeloid metaplasia with myelofibrosis. Cancer Cell. 2005;7(4):387-397.

78. Baxter EJ, Scott LM, Campbell PJ, et al. Acquired mutation of the tyrosine kinase JAK2 in human myeloproliferative disorders. Lancet. 2005;365(9464):1054-1061.

79. Zhao R, Xing S, Li Z, et al. Identification of an acquired JAK2 mutation in polycythemia vera. J Biol Chem. 2005;280(24):22788-22792.

80. Scott LM, Tong W, Levine RL, et al. JAK2 exon 12 mutations in polycythemia vera and idiopathic erythrocytosis. N Engl J Med. 2007; 356(5):459-468.

81. Pietra D, Li S, Brisci A, et al. Somatic mutations of JAK2 exon 12 in patients with JAK2 (V617F)-negative myeloproliferative disorders Blood. 2008;111(3):1686-1689.

82. Pardanani A, Lasho TL, Finke C, Hanson CA, Tefferi A. Prevalence and clinicopathologic correlates of JAK2 exon 12 mutations in JAK2V617Fnegative polycythemia vera. Leukemia. 2007;21(9):1960-1963.

83. Wang YL, Vandris K, Jones A, et al. JAK 2 mutations are present in all cases of polycythemia vera. Leukemia. 2008;22(6):1289.
84. Saharinen P, Takaluoma K, Silvennoinen O. Regulation of the JAK2 tyrosine kinase by its pseudokinase domain. Mol Cell Biol. 2000;20(10):3387-3395.

85. Quintás-Cardama A, Manshouri T, Estrov Z, et al. Preclinical characterization of atiprimod, a novel JAK2 and JAK3 inhibitor. Invest New Drugs. 2011;29(5):818-826.

86. US Food and Drug Administration. Jakafi (Ruxolitinib) label. Silver Spring, MD: FDA; 2011. Available from: http://www.accessdata.fda.gov/ drugsatfda_docs/label/2011/202192lbl.pdf. Accessed Jan 4, 2012.

87. ClinicalTrials.gov. Study of ruxolitinib (INCB018424) administered orally to patients with androgen independent metastatic prostate cancer Bethesda, MD: National Institutes of Health; 2012. Available from: http:/clinicaltrials.gov/ct2/show/study/NCT00638378?sect=X3015\& view=results. Accessed February 13, 2012.

88. ClinicalTrials.gov. Study to assess safety, tolerability and PK of AZD1480 alone or in comb with docetaxel in patients with solid tumours. Bethesda, MD: National Institutes of Health; 2012. Available from: http://clinicaltrials.gov/ct2/show/NCT01112397?term=AZD148 0\&rank=2. Accessed Feb 13, 2012.

89. Pardanani A. JAK2 inhibitor therapy in myeloproliferative disorders: rationale, preclinical studies and ongoing clinical trials. Leukemia. 2008;22(1):23-30.

90. Pardanani A, Hood J, Lasho T, et al. TG101209, a small molecule JAK2-selective kinase inhibitor potently inhibits myeloproliferative disorder-associated JAK2V617F and MPLW515L/K mutations. Leukemia. 2007;21(8):1658-1668.

91. Tyner JW, Bumm TG, Deininger J, et al. CYT387, a novel JAK2 inhibitor, induces hematologic responses and normalizes inflammatory cytokines in murine myeloproliferative neoplasms. Blood. 2010; 115(25):5232-5240.

92. Hart S, Goh KC, Novotny-Diermayr V, et al. SB1518, a novel macrocyclic pyrimidine-based JAK2 inhibitor for the treatment of myeloid and lymphoid malignancies. Leukemia. 2011;25(11):1751-1759.

93. Nakaya Y, Shide K, Niwa T, et al. Efficacy of NS-018, a potent and selective JAK2/Src inhibitor, in primary cells and mouse models of myeloproliferative neoplasms. Blood Cancer J. 2011;1(7):e29.

94. Santos FP, Kantarjian HM, Jain N, et al. Phase 2 study of CEP-701, an orally available JAK2 inhibitor, in patients with primary or postpolycythemia vera/essential thrombocythemia myelofibrosis. Blood. 2010;115(6):1131-1136.
OncoTargets and Therapy

\section{Publish your work in this journal}

OncoTargets and Therapy is an international, peer-reviewed, open access journal focusing on the pathological basis of all cancers, potential targets for therapy and treatment protocols employed to improve the management of cancer patients. The journal also focuses on the impact of management programs and new therapeutic agents and protocols on

\section{Dovepress}

patient perspectives such as quality of life, adherence and satisfaction. The manuscript management system is completely online and includes a very quick and fair peer-review system, which is all easy to use. Visit http://www.dovepress.com/testimonials.php to read real quotes from published authors. 